SELDEN, JOHN (1584-1654). In his History of Tithes (1618) this famous antiquarian, lawyer and parliamentarian upheld their legal right but denied their divine authority, hence the book was suppressed. In 1647 he published the first printed edition of the old English lawbook, Fleta.

Can 51

Fleta, seu Commentarius Juris Anglicani sic nuncupatus, Osg sub Edwardo rege primo ... Editio secunda, multis erroribus purgata.

London: S.R.Prostant for H.Twy ford, T. Bassett, J. Place \& S. Keble, 1685.

Can 52

London: 1618 . - The Historie of Tithes. [STC 22172]

\title{
THE SALZBURG COLLECTION
}

is the name of a section of the Library of the University of Alberta. It is constituted by the older part of the law library of the Archbishop of Salzburg and was acquired by the University of Alberta in 1966. This law library was started in 1579 with donations from various ecclesiastical sources. The collection in the University of Alberta comprises 3500 volumes (partly uncatalogued). The oldest volume is an Infortiatum from 1488; there are several more volumes from the 15th century, 350 volumes from the 16th century, several hundred from the 17th century. The older part of this collection is nearly all canon law, and it is the most comprehensive Canadian collection of its kind.

Communication by G. Hermansen, Department of Classics, University of Alberta

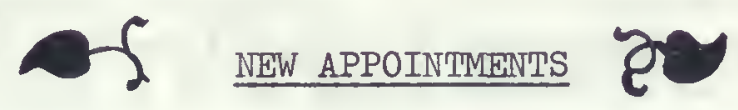

Allen B. Cameron, English, University College, U.of T, Renaissance nondramatic literature

Walter E.T.Creery, Founders' College, York U, philosophy of religion, Ockham

Stillman Drake, History and Philosophy of Science, U of T, Galileo Sandra Johnston, English, Victoria, U of T, Drama Martin Mueller, English, University College, U of T, Milton Giuseppe Scavizzi, Fine Arts, Scarborough, U of T, Baroque Art, Pietro da Cortona

Olga Zorzi, Italian and Hispanic Studies, U of T, Italian literature, Benivieni 